\title{
Thymus pulegioides Leaf Oil
}

National Cancer Institute

\section{Source}

National Cancer Institute. Thymus pulegioides Leaf Oil. NCI Thesaurus. Code C72208.

The essentail oil extracted from the leaves of Thymus pulegioides. Lemon thyme oil is used in parfumery and in medicinal preparations. 